ROCZNIKI NAUK PRAWNYCH

Volume XXVIII, number 3-2018

E n g $1 \mathrm{ish}$ ve r s i o

DOI: http://dx.doi.org/10.18290/rnp.2018.28.3-12en

PAWEŁ KALETA

\title{
LEGAL REQUIREMENTS FOR PIOUS DISPOSITIONS OF WILL ACCORDING TO THE 1983 CODE OF CANON LAW
}

Pious dispositions of will follow from the faith of Man and are intended to plead for grace or blessing for the donors. ${ }^{1}$ So they have a pious, religious purpose. Lawfully accepted pious wills are usually fulfilled by: 1) establishing a specific pious work resulting from the act of the donor, 2) transferring goods to an already existing juridical person as separate property (nonautonomous pious foundation); or 3) establishing a separate legal institution with legal personality (an autonomous pious foundation).

Title IV of Book V of the 1983 Code of Canon $\mathrm{Law}^{2}$ is a distinct set of provisions designed to govern pious dispositions and pious foundations. In view of the organisation of the legal provisions of Book $\mathrm{V}$ in CIC/83, the aforementioned Title IV Pious Wills in General and Pious Foundations supplements Book V. ${ }^{3}$ This is due to the fact that the goods destined for pious works also constitute ecclesiastical goods (bona ecclesiastica) and are subject to the provisions of Book V and their own statutes (c. 1257, §1). The legal norms contained in Title IV of Book $\mathrm{V}$ are intended to provide legal protection of pious dispositions against incidental acts of the executor and an effective tool in fulfilling pious wills with "most diligently" (see c. 1300).

Rev. Pawee KAlETA, JCD, is an assistant professor at the Department of General Norms and Church Patrimonial Law, Institute of Canon Law, Faculty of Law, Canon Law and Administration of the John Paul II Catholic University of Lublin (KUL); address: Racławickie 14, 20-950 Lublin, Poland; e-mail: kaleta@kul.pl; https://orcid.org/0000-0001-6159-0997.

${ }^{1}$ See G. VRomant, De bonis Ecclesiae temporalibus, 3rd ed (Brussels: Éditions de Scheut, 1953), 137.

${ }^{2}$ Codex Iuris Canonici auctoritate Ioannis Pauli PP. II promulgatus, January 25, 1983, AAS 75 (1983), pars II, 1-317; Kodeks Prawa Kanonicznego, translation approved by the Polish Episcopal Conference (Poznań: Pallottinum, 1984); the Translator used the CLSA English version made available on the Vatican website [hereafter CIC/83].

${ }^{3}$ Pontifical Commission for the Revision of the Code of Canon Law, Acta commissionis, Communicationes 5, no. 1 (1973): 101. 
Our goal is to analyse the legal provisions concerning pious wills provided for by the CIC/83. The article does not address pious foundations. In CIC/83, the legislator explicitly distinguishes pious wills (cc. 1299-1302) from pious foundations (cc. 1303-1307). It is worth noting, however, that the institution of a pious foundation is but one form of effective implementation of pious dispositions of will, which is governed by separate legal dispositions. $^{4}$

The research problem, which now must be formulated goes as follows: what are the legal requirements for a legitimate acceptance (legitime acceptate) of a pious disposition of will? In response to this, the concept of "pious wills" should be clarified first to be able to indicate legal requirements concerning legitimate acceptance of pious dispositions. Further on, we will look at the ways to implement pious wills.

\section{THE CONCEPT OF PIOUS WILL}

The term "pious will" is derived from the Latin adjective pius, - $a$, -um, which means "pious" or "God-fearing" and from the noun voluntas, -atis, which denotes "will" or "declaration of will." It is worth noting, however, that the Latin expression pia voluntas in the Polish translation of CIC/83approved by the Polish Episcopal Conference (April 9, 1983) — was translated as pobożny zapis [pious legacy-Translator's note], ${ }^{8}$ which, however, does not render the Latin term correctly. The same phrase, used in Chapter IV of Title XXIII of the Code of Canons of the Eastern Churches, ${ }^{9}$ was also translated as pobożne zapisy $w$ ogólności i pobożne fundacje. It is significant,

\footnotetext{
${ }^{4}$ See P.V. PINTo, Commento al Codice di Diritto Canonico (Vatican City: LEV, 2001), 747.

${ }^{5}$ J. SONDEL, Stownik tacińsko-polski dla prawników i historyków (Kraków: Universitas, 1997), 752.

${ }^{6}$ F. FALCHI, "Le pie volontà." In AA. VV., I Beni temporali della Chiesa (Vatican City: LEV, 1999), 167.

${ }^{7}$ Polish Episcopal Conference, Decree No. 1601/83/P, in Kodeks Prawa Kanonicznego, 4.

${ }^{8}$ [The same translation is used in Codex Iuris Canonici. Kodeks Prawa Kanonicznego. Komentarz. Powszechne i partykularne ustawodawstwo Kościoła katolickiego. Podstawowe akty polskiego prawa wyznaniowego, ed. P. Majer, Polish edition based on Spanish edition (Kraków: Wolters Kluwer Polska, 2011), 971.

${ }^{9}$ Codex Canonum Ecclesiarum Orientalium auctoritate Ioannis Pauli PP. II promulgatus, October 18, 1990, AAS 82 (1990), 1033-363; Polish translation in Kodeks Kanonów Kościołów Wschodnich promulgowany przez Papieża Jana Pawta II, trans. L. Adamowicz and M. Dyjakowska (Lublin: Wydawnictwo Archidiecezji Lubelskiej "Gaudium," 2002) [henceforth quoted as CCEO].
} 
however, that both Franciszek Bączkowicz ${ }^{10}$ and Tadeusz Pawluk, ${ }^{11}$ in their own commentaries on canon law, translate the Latin pia voluntas as pobożne rozporzadzenie woli [pious disposition of will-Translator's note]." In turn, Walenty Wójcik, translates the phrase pia voluntas literally as pobożna wola [pious will-Translator's note]. ${ }^{12}$ Although these canonists correctly translated the Latin phrase [into Polish] as "pious disposition of will," the contemporary Polish canonist literature still employs the erroneous translation of the Latin phrase de piis voluntatibus. ${ }^{13}$

In terms of secular law, the term "legacy" refers to inheritance $l_{a w}{ }^{14}$ and is narrower than the concept of pious disposition, which embraces acts made inter vivos and mortis causa. For this reason, it can be hardly accepted that the Polish translation of Title IV of Book V CIC/83 should correctly reflect the true intention of the legislator.

According to the established canonical tradition, pious dispositions of will are dispositions of both movable and immovable goods made inter vivos and mortis cousa for the purpose of carrying out works of piety or charity, that is, for the proper purposes of temporal goods of the Church mentioned in canon $1254, \S 1 .^{15}$ The Latin adjective pia is a criterion for distinguishing whether a donation is for pious works or not. Therefore, piety is an important purpose of a donation. The plural noun voluntatibus, on the other hand,

${ }^{10}$ F. Bączkowicz, J. BAron, and W. Stawinoga, Prawo Podręcznik dla duchowieństwa (Opole: Wydawnictwo Diecezjalne św. Krzyża, 1958), 2: 558.

${ }^{11}$ T. PAwluk, Prawo kanoniczne wedtug Kodeksu Jana Pawta II, vol. 4, Dobra doczesne Kościoła. Sankcje w Kościele. Procesy (Olsztyn: Włocławski Wydawnictwo Diecezjalne, 2009), 53.

${ }^{12}$ W. WósciK, "Dobra doczesne Kościoła," in Księga V. Dobra doczesne kościoła. Księga VI. Sankcje w Kościele, vol. 4 of Komentarz do Kodeksu z 1983 r., by W. WóJCIK, J. KRUKOWSKI, and F. LEMPA (Lublin: Redakcja Wydawnictw KUL, 1987), 94. A comparative reference can be made to the exegetical commentary on the Code of Canon Law, in which the Latin piis voluntatibus was translated as 'pious dispositions,' see J.M. VÁzQuEZ GARCíA-PeñUela, "Pious Dispositions in General and Pious Foundations," in Exegetical Commentary on the Code of Canon Law, ed. Á. Marzoa, J. Miras, and R. Rodriguez-Ocaña (Montreal-Chicago: Wilson \& Lafleur, 2004), 150.

${ }^{13}$ T. GaŁKowsKI, "Pobożny zapis i pobożna fundacja," Prawo Kanoniczne 52, nos. 3-4 (2009): 317-35; M. LóPez Alarcón, "Dobra doczesne Kościoła," in Codex Iuris Canonici. Kodeks Prawa Kanonicznego, 971; A. WARmuZ, "Pobożne zapisy jako sposób pozyskiwania dóbr doczesnych w Kodeksie Prawa Kanonicznego z 1983 r. i partykularnym prawie polskim,” Kościót i Prawo 1 (2012): 153-66; D. WALENCIK, "Fundacje zakładane przez osoby prawne Kościoła Katolickiego w Polsce a fundacje pobożne," Studia z Prawa Wyznaniowego 16 (2013): 65-91; P. KALETA, Kościelne prawo majątkowe (Lublin: Towarzystwo Naukowe KUL, 2014): 70; A. DomaszK, Dobra doczesne Kościoła (Warszawa: Wydawnictwo UKSW, 2016), 283.

${ }^{14}$ Art. 922-30 of the Act of 23 April 1964-The Civil Code, Journal of Laws of 2017, item 459 [hereinafter referred to as CC].

${ }^{15}$ L. ChiappetTa, Il Codice di Dirito Canonico, (Bologna: EDB, 2011), 2:603. 
refers to a person's will according to which the donor may freely dispose of his or her own property.

Pious dispositions of will, as indicated in the introduction, spring from Man's faith, that is, from supernatural causes, and are intended to ask for grace or blessing. Therefore, they have a pious purpose, for example worship of God, in particular to transfer certain property for the celebration of Mass, as a compensation for one's or another's sins, or for works of charity. However, pious dispositions of will must not be confused with humanitarian or philanthropic works. ${ }^{16}$ In the literature on the Code of Canon Law of $1917^{17}$ it was argued that the works of piety also refer to acts of Christian charity, ${ }^{18}$ donations for the poor or "for the Church." 19 It seems, however, that this interpretation of pious dispositions of will is too broad, as it may blur the distinctions between a pious will and a donation for charitable works of the Church. What distinguishes a disposition of will from a donation for the above-mentioned works is a pious intention because without this it would be difficult to speak of a supernatural reality. The will of the person making a disposition transpires from the attitude of the donor, which results from an act of faith and piety. ${ }^{20}$

In the literature of the subject there is some discussion whether a non-believer can make a disposition of will for a pious cause. ${ }^{21}$ To answer this question, we should first make it clear that a pious disposition of will can be considered from both a moral and a legal point of view. Either will be appraised differently.

From a moral point of view, a pious act of will is identified with supernatural grace, which is actualised in a pious act. It is therefore difficult to accept that a non-believer who has no link with God should be able to dispose of his or her property for a pious cause, for instance to offer Mass for a specific intention. However, things are different if the donor is a believer

\footnotetext{
${ }^{16}$ T.L. Bouschren, A.Ch. Ellis, and F.N. Korth, Canon Law. A Text and Commentary (Milwaukee: Bruce Publishing Co, 1963), 821.

${ }^{17}$ Codex Iuris Canonici auctoritate Pii X Pontificis Maximi iussu digestus. Benedicti Papae XV auctoritate promulgatus, May 27, 1917, AAS 9 (1917), pars II, 2-523 [henceforth quoted as CIC/17].

${ }^{18}$ I. GRABOwsKi, Prawo kanoniczne wedtug nowego Kodeksu (Lviv: Towarzystwo Biblioteka Religijna, 1927), 569.

${ }^{19}$ BączKowicz, Baron, and Stawinoga, Prawo kanoniczne, 558.

${ }^{20}$ GaŁkowsKi, Pobożny zapis, 321.

${ }^{21}$ Ibid., 322; Domaszk, Dobra doczesne Kościoła, 284; LóPEZ Alarcón, Dobra doczesne Kościoła, 972.
} 
and a person known in the community for his or her piety. Then the intention of making a disposition for pious causes will not give rise to any doubt.

From a legal point of view, the assessment of a pious disposition will be seen differently. Please note that canon 1299, §1 provides that anyone [emphasis by P.K.] may dispose of his or her own property for a pious cause unless natural or canonical law prevents them from doing so. Therefore, if the intention is expressed in a legal form towards the Catholic Church or for the benefit of an ecclesiastical institution, such an act falls within the competence of the Church. Canon law does not expressly rule out donors' good intentions as well as the legal actions of other people who are non-believers. ${ }^{22}$

The situation at hand leads to the conclusion that in the case of a non-believer, that is, a person not guided by a supernatural intention, we can say that he or she can make a pious disposition of will only in the legal sense. Nonetheless, in a moral sense, when the donor has no supernatural motivation (intentions), it is not possible to speak of a pious disposition of will. ${ }^{23}$

\section{LEGAL REQUIREMENTS FOR MAKING DISPOSITIONS FOR PIOUS CAUSES}

In canon $1299, \S 1$, it is provided that the required capacity to dispose of goods for pious causes is determined in each case by natural and canonical law. In this regard, anyone who, under natural or canon law, has the possibility to dispose freely of his property may dispose of it for pious causes, either by an act among the living or by an act upon death, even if civil law denies that right. ${ }^{24}$ Under natural law, the limitations are: inability to act reasonably (see cc. 97, §2 and 99). Under canon law, these limitations include, among others, the lack of use of reason (children under 7 years of age), intoxicated with alcohol and persons acting under external coercion, which in no way can be resisted. ${ }^{25}$ Other requirements of canon law relate to the capacity of religious of disposing of their property after perpetual vows (c. $668, \S 5)$. In the context of legal requirements, it should be added that canon 1285 provides for the possibility of making pious donations by eccle-

\footnotetext{
${ }^{22}$ DomaszK, Dobra doczesne Kościoła, 284.

${ }^{23}$ V. De PAOLIS, Il Codice del Vaticano II. I Beni temporali della Chiesa (Bologna: Edizioni Dehoniane, 2001), 226; see also DomAszK, Dobra doczesne Kościoła, 284.

${ }^{24}$ L. ChiappetTA, Il Codice di Dirito Canonico, 602.

${ }^{25}$ V. De PaOLIS, De bonis Ecclesiae temporalibus. Adnotationes in Codicem. Liber V (Rome: Gregorian University, 1986), 111.
} 
siastical juridical persons two requirements are observed: 1) the donation is made from movable property which is not part of stable patrimony (patrimonium stabile) and 2) this activity will be part of ordinary administration. ${ }^{26}$

Since canon 1299, §1 explicitly refers to the provisions of natural and canon law, the question may arise whether the provisions of state law should be observed in the making of dispositions for pious causes. It is worth noting that in the case of property dispositions upon death, the legislator expressly provides in canon 1299, $\$ 2$ that civil law must be observed as far as possible. In the case of dispositions of will among the living, on the other hand, no such reference is made. To address this problem, we need to refer to canon 1290, which prescribes the observance of the rules of law in matters which concern contracts and property obligations, provided that the state law is not contrary to the Divine Law, or canon law does not provide otherwise. It should be pointed out that canon 1290 makes explicit reference to contracts in general and to specific contracts (de contractibus tam in genere, quam in specie). Dispositions made inter vivos and mortis causa belong to the category of specific contracts. Consequently, when making pious dispositions of will, provisions of civil law must also be observed, unless they expressly oppose canon law. ${ }^{27}$

When answering the question concerning the obligation to comply with state law, one should also mention canon 1300, which states that all dispositions of the faithful made for pious causes are to be legitimately accepted (legitime acceptatae). ${ }^{28}$ This compliance with the law applies not only to canon law but also to civil law. With regard to the tasks of the administrator, the legislator states in canon $1284, \S 2,3^{\circ}$ that all administrators must observe the norms of canon and civil law and the norms imposed by the founder,

\footnotetext{
${ }^{26}$ See P. KAlETA, Prawne aspekty zarządzania dobrami doczesnymi Kościoła (Lublin: Wydawnictwo, KUL 2017), 126-27.

${ }^{27}$ See J.A. Renken, "Pious Wills and Pious Foundations," Philipine Canonical Forum 10 (2008): 81.

${ }^{28}$ However, it is difficult accept the opinion presented by Agata Warmuz, who claims that "the legislator indicated that in the case of donations disposed upon death, the provisions of the domestic civil law must be observed. The team of consultors working on the wording of this canon proposed that the requirement of observing civil law should also apply to acts made among the living," IDEM, Pobozine zapisy, 154-55. Both acts made among the living and those made upon death are governed by contracts. As a result, canon 1290 must be complied with, which states that "The general and particular provisions which the civil law in a territory has established for contracts and their disposition are to be observed with the same effects in canon law insofar as the matters are subject to the power of governance of the Church unless the provisions are contrary to divine law or canon law provides otherwise, and without prejudice to the prescript of can. 1547."
} 
so that the Church is not harmed when not observing civil laws. The order of obligations provided for by canon $1284, \S 2$ is not random, because the administrator of ecclesiastical property must first observe the provisions of canon law and then the provisions of civil law. This is due to the fact that canon law may provide otherwise, in particular prescripts related to the acceptance of donations with a condition stipulated or in a specified manner (c. 1267, $\S 2$ ), acceptance of dispositions of the faithful upon death (c. 1301, §3), or a valid acceptance of a non-autonomous foundation, as provided for in canon $1304, \S 1{ }^{29}$ Adherence to the requirements of canon and civil law can protect the Church against accidental acceptance of pious dispositions of property that could impose on ecclesiastical entities their own manner of fulfilling pious dispositions that do not necessarily correspond to the proper purposes of ecclesiastical goods (c. 1254, §2).

\section{WAYS TO EFFECT PIOUS DISPOSITIONS OF WILL}

In accordance with canon $1299, \S 1$, the transfer of goods for pious causes can be done in several ways: 1) inter vivos (e.g. a donation agreement); 2) mortis causa (e.g. by a last will and testament, testamentary legacy, bequest); and 3) trusteeship for pious causes (c. 1302). The first has its effect in the donor's lifetime, whereas the other after the donor's death. The latter is a form of trusteeship for pious causes. ${ }^{30}$

Due to the fact that the ecclesiastical legislator envisages separate legal requirements concerning acts made inter vivos, mortis causa and by way of trusteeship, they will be analyzed below in succession.

\subsection{Acts Inter vivos}

The Latin phrase inter vivos means that one's assets are disposed of by way of an act between living people. They usually take the form of a donation, which is a bilateral agreement whereby the donor undertakes to make a donation free of charge to the beneficiary at the expense of his or her own property. ${ }^{31}$ An important feature of a donation is the absence of an equivalent corresponding to the donor's grant. In practice, a donation follows from

\footnotetext{
${ }^{29}$ Renken, Pious Wills and Pious Foundations, 84.

${ }^{30}$ The legal structure of trusteeship was not fully specified and regulated in the Polish civil law.

${ }^{31}$ J. Jeziono, "Darowizna," in Kodeks cywilny. Komentarz, $8^{\text {th }}$ ed., ed. E. Gniewek and P. Machnikowski (Warszawa: Wydawnictwo C.H. Beck, 2017), 1634.
} 
the donor's feelings and attitudes, which are referred to as "higher." In the canonical legal system, donations made by the faithful should, in principle, be accepted by the administrator (c. 1267, \$2 in principio) and should be used in accordance with the purpose specified by the donor (c. 1267, §3). These donations are in fact pious acts of the faithful. They also demonstrate the bond existing between the faithful and the Church. Many of these offerings are bestowed for works of charity, piety or apostolate (c. 114, §2), which are transmitted through an ecclesiastical juridical person (e.g. parish, religious house). Therefore, the administrator should not refuse to accept an offering (c. 1267, §2). A potential refusal could deprive the Church of the useful goods that are necessary for her mission. ${ }^{32}$ However, an offering may be refused for a grave cause and in matters of greater importance with the consent of the ordinary. The Episcopal Conference of Poland, in its Instruction on the administration of temporal goods of the Church $^{33}$ states that such a grave cause may be, among others, the vile origin of temporal goods, the donor's lack of good faith, the nature of the thing donated, its appearance or purpose (Instruction 2,9). Accepting such an offering could give rise to defamation of the Church or a loss of public confidence. Therefore, before accepting them, the administrator should verify the object of the offering (donation), whether it is moral and decent, whether it will not be a liability to the ecclesiastical juridical entity and whether there are no hidden liabilities in it. ${ }^{34}$ The second condition justifying rejection of an offering is the existence of matters of greater importance. In the Polish translation of canon $1267, \S 2$, the Latin phrase in rebus maioris momenti is rendered as "sprawy większej wagi [matters of greater weight]." On the other hand, the same wording of canon 1277 was translated as "sprawy o większym znaczeniu [matters of greater importance]." These more important matters typically relate to the value of the offering (donation), which can have an impact on the economic condition of a legal entity. However, CIC/83 does not specify who is entitled to determine acts of greater significance; or what which value of the donated thing should be considered as being of greater significance. Taking into account the parallel text locations, we can point to canon 1277, in which the criterion for the recognition of matters of greater importance is provided: the economic condition of the diocese. However, this precept applies only to

\footnotetext{
${ }^{32}$ V. DE PAOLIS, I beni temporali della Chiesa, new ed., rev. and cons. by A. Perlasca (Bologna: EDB, 2016), 159.

${ }^{33}$ EPISCOPAL CONFERENCE OF POLAND, Instruction on the administration of the temporal goods of the Church, Akta Konferencji Episkopatu Polski 27 (2015): 116-40.

${ }^{34}$ KAlETA, Prawne aspekty zarzadzania dobrami, 138.
} 
dioceses; for other legal persons, reference should be made to the statutes of a juridic person (c. 117). ${ }^{35}$ If the statutes do not specify matters of greater importance, the administrator should deal with them according to his own criteria, taking into account, for example, the economic condition of the legal person (compare can. 1277). In order to refuse to accept a more significant offering-except for a grave reason-the ordinary should obtain the necessary information about the offering. The obligation to submit complete documentation rests with the administrator of the juridic person who is to accept the donation. The written consent of the ordinary is required in order to refuse an offering both for serious reasons and on account of greater importance. It is worth noting that the notion "ordinary" is a broader concept than "diocesan bishop," therefore the legal disposition referred to in canon 1267 , §2 must also be complied with in the case of clerical religious institutes of pontifical right and clerical societies of apostolic life of pontifical right (c. 134). If an offering of a greater significance is rejected without the consent of the ordinary, the legislator does not provide for a criminal sanction. However, it is possible to claim compensation for any damage or loss that may have occurred (c. 128) ${ }^{36}$ As regards private juridic persons, refusal to accept an offering of a greater significance should be regulated by its statute. Pursuant to canon 1257, §2, the temporal goods of a private legal entity are governed by its own statutes. ${ }^{37}$

A different situation is defined by canon $1267, \S 2$, namely acceptance of an offering encumbered by a modal obligation or a condition. It should be noted that the acceptance of a offering with a stipulated condition may cause the property status of the church legal entity to deteriorate, so canon 1295 must be obeyed, in which the legislator refers to observance of the provisions on alienation (cc. 1291-4). In its Instruction, the Polish Episcopal Conference provides examples of acceptance of donations with the manner of execution specified: donations encumbered with mortgages, pledges, easements and leases (Instruction 2,9). Pursuant to canon 1267, §2, in order to accept such a donation, a written consent of the ordinary is required. As in the first case, it is the responsibility of the administrator to provide all information concerning the donation subject to a condition. The prudence of administration suggests that a donation should be rejected if the condition

\footnotetext{
${ }^{35}$ R.T. KenNEDy, "The Temporal Goods of the Church," in New Commentary on the Code of Canon Law, ed. J.B. Beal, J.A. Coriden, and T.J. Green (Mahwah-New York: Paulist Press, 2000), 1469.

${ }^{36}$ See also LóPez Alarcón, Dobra doczesne Kościoła, 941.

${ }^{37}$ KALETA, Prawne aspekty zarzadzania dobrami, 138.
} 
stipulated in the donation agreement is for an indefinite period of time, regardless of the amount of the offering. This is because long-term commitments (e.g. for periods of twenty years) can be too burdensome for church legal entities. Account should also be taken of changing economic circumstances, which over time may become disadvantageous for such an entity. However, a donation for a definite period of time is a different matter. If such an agreement is beneficial for an ecclesiastical juridical entity and if it stipulates a condition that it can be amended by the diocesan bishop for its duration, then such a donation should be accepted. ${ }^{38}$

The causes of pious dispositions of will should be consistent with their objectives, that is, they should be intended for pious causes, for example the celebration of Mass for a specific intention. However, attachment of a condition imposing the manner in which a donation is to be used may violate the principles of social order in the Church. In case of doubts arising about the acceptance of such a donation, save for canon 1267, §2, we can also to refer to canon 1300 , in which the legislator provides that the ordinary is the executor of all the pious dispositions [emphasis-P.K.], made both by way of a will and as an act among the living. The ordinary, in order to accept a donation subject to a condition or specific use, pursuant to canon 1267, §2, should grant his written consent (licentia).

In conclusion, it should be stressed that pious dispositions of will made inter vivos, when lawfully accepted, should be executed with utmost diligence (diligentissime). The fulfilment of such a disposition concerns not only the administration of these goods, but also their use (canon 1300).

\subsection{Acts mortis causa}

The second way to make a pious disposition of will is through an act made mortis causa. This is a unilateral, personal and unrestricted act, addressing a specific person (heir), containing the testator's last will concerning his or her property upon death. ${ }^{39}$ A pious will may take the form of an ordinary will, ${ }^{40}$ a testamentary legacy, or legatum. Pursuant to Article $968 \S 1$ of

\footnotetext{
${ }^{38}$ F.G. MORRISEY, "The Temporal Goods of the Church," in The Canon Law. Letter \& Spirit. A Practical Guide to the Code of Canon Law, ed. G. Sheehy et al. (Collegeville, Minn.: Liturgical Press, 1995), 716; KaleTa, Prawne aspekty zarzadzania dobrami, 139.

${ }^{39}$ J. KuŹMiCKA-SuliKowsKa, "Pojęcie testamentu," in Kodeks cywilny. Komentarz, 1803.

${ }^{40}$ It should be noted that the CIC/83 legislator uses different terms [in the Polish translation of the Code-Translator's note; see also other notes that follow] for acts made for the event of death-[Polish] testament in cc. 1299, §1;1300;1301, §1; 1302, §1 [= act/will mortis causa]), and [Polish] ostatnia wola in c. 1301, $\$ 3$ [= last will and testament). Ostatnia wola differes from
} 
the Polish Civil Code, a legacy is a commitment of a statutory or testamentary heir to provide a specific property benefit to a designated person. The testator may oblige the heir to bestow part of his or her assets for pious causes. Another form of last-will dispositions under canon law are legata, provided for by canon 1308, §3. In canon law, the Latin term legatum denotes "testamentary legacy" whereby a testator bestows his assets for the celebration of Mass. Legata can be independent (legata per se stantia) if they are separate foundations not backed by other property dispositions, so that their losses are not compensated by general income. ${ }^{41}$

In the canonical legal system, the will of the testator is binding. In the implementation of a disposition made for the event of death,${ }^{42}$ the legislator prescribes, where possible (si fieri possit), that civil law be observed (c. $1299, \S 2$ ). The use of a conditional form in canon 1299, §2 indicates that compliance with the requirements of state law is not mandatory but conditional. The reason for this is that some state laws may not recognise the economic capacity of ecclesiastical legal entities, or may restrict their activities in a particular territory, or may not recognise canon law requirements for the acquisition of property. ${ }^{43}$ If civil law did not recognise the economic capacity of ecclesiastical legal persons or banned the making of pious wills, then they should be considered ineffective under canon law. ${ }^{44}$ It is recognised that under natural law anyone who has acquired the capacity to perform legal acts may effect property dispositions. ${ }^{45}$

In the Polish legal system, both Article 52 of the Act of 17 May 1989 on the relationship between the State and the Catholic Church in the Republic of Poland, ${ }^{46}$ as well as Article 23 of the Concordat between the Holy See and

testament in that it can no longer be changed. It occurs when the testator wrote a will and died and did not change his own will with another will. Then such a testament is legally defined as the testator's ostatnia wola [=last will and testament].

${ }^{41}$ See also PAwLuK, Prawo kanoniczne, 60.

${ }^{42}$ It should be noted that c. $1043, \S 2$ CCEO refers to the last will and testament and not to dispositions mortis causa, as in can. $1299, \S 2$. According to Robert Kennedy, this should not be interpreted as a narrower meaning of a disposition mortis causa, since in the canonical tradition the term "last will" is understood as all acts made for the event of death which are referred to as donatio in mortis causa, see IDEM, The Temporal Goods of the Church, 1511-12.

${ }^{43}$ Renken, Pious Wills and Pious Foundations, 81.

${ }^{44}$ VaZQueZ Garcia-Peñuela, Pious Dispositions, 151.

45 [Under Polish law - Translator's note] capacity to perform legal acts is vested in adults, natural persons who are not incapacitated and all legal persons (see Art. 8-24 CC).

${ }^{46}$ Journal of Laws of 2018, item 380. 
the Republic of Poland signed in Warsaw on 28 July $1993,{ }^{47}$ recognise the economic capacity of church juridic persons and do not prohibit the making of property dispositions for pious causes to persons who have acquired the capacity to perform legal acts. Therefore, the provision of $1299, \S 2$ does not apply to the Church in Poland. Church legal entities are obliged to implement dispositions of last wills and respect the state law. This in particular concerns the observance of general provisions (Art. 941-8 of the Polish Civil Code), the form of wills (Art. 949-58), the appointment of an heir (Art. 959-67), the provisions on legacies and testamentary instructions (Art. 968-1087), and the executor of a will (Art. 986-1087). The provisions of state law must be complied with irrespective of the person of the addressee or the author of a pious will, ${ }^{48}$ without prejudice to canon $1301, \S 3$, providing that a stipulation attached to a last will which is contrary to the ordinary's right should be considered non-existent.

In the event that the heir ignores the testator's last will for a pious disposition, the ordinary is obliged to advise the heirs that they are under an obligation to fulfil the testator's will (c. 1299, §2). It is worth noting, however, that the ordinary's power to admonish his heirs does not apply to all wills, but to those which contain a legacy for a pious cause. The ordinary should only remind the heirs of the execution of the testator's will if he is certain that the testator bestowed part of the property for a pious cause. ${ }^{49}$ This obligation rests with the ordinary, since he is the executor of all pious dispositions made either mortis causa or inter vivos (c. 1301, §1). According to the explanation of the Pontifical Commission for Authentic Interpretation of the Code of Canon Law of February 17, 1930, in the case of failure to apply the provisions of civil law due to negligence, statutory prohibition or any other reason, there is a duty to remind the heirs to fulfil the will of the testator in their conscience and in favour of the Church. ${ }^{50}$

The provision of canon 1299, $\$ 2$ is intended to avoid possible conflicts that may arise among heirs appointed in the will or resulting from statute. However, the obligation to remind the heirs is not absolute, If the reminder were to harm the interest of the Church, this obligation must be abandoned.

\footnotetext{
${ }^{47}$ Journal of Laws of 1998, No. 51, item. 318; Sollemnis conventio inter Apostolicam Sedem et Poloniae Rem Publicam, July 28, 1993, AAS 90 (1998), 310-29.

${ }^{48}$ P. MAJER and J. SiŃSKI, "Dodatek dotyczący prawa polskiego do komentarza kan. 1299," in Codex Iuris Canonici. Kodeks Prawa Kanonicznego, 972.

${ }^{49}$ Wóscik, Dobra doczesne Kościoła, 96.

${ }^{50}$ AAS 22 (1930), 196.
} 
The assessment of the legal status must take into account the specific circumstances. ${ }^{51}$

In the canonical legal system, the ordinary is the executor of all pious wills made both inter vivos and mortis causa. ${ }^{52}$ It is the ordinary who has executive power over a person who has accepted a pious disposition of will. In the state legal system in Poland, the executor of a will or a testamentary legacy is a person indicated by the testator (Article 986, $\$ 1$ CC). It should be stressed, however, that the canonical notion of "executor" has a different meaning than in secular law. In canon law, the term refers to executive power (potestas exsecutiva) of the ordinary and stresses his responsibility for the fulfilment of a pious disposition. ${ }^{53}$ This does not mean, however, that the Ordinary is to be the direct and sole executor of dispositions for pious causes. Pursuant to canon 1301, §2, an ordinary can and should be vigilant (vigilare potest ac debet) so that the pious wills submitted to any person (legal or natural) may be carried out with the utmost care. We should also mention canon $325, \S 2$, which refers to private associations of the faithful. ${ }^{54}$ If the last will does not nominate an executor of the pious disposition or the executor indicated in it has committed serious violations, the ordinary himself is obliged to fulfil the pious will or delegate an appropriate person for this task. ${ }^{55}$ However, free designation of the executor of a pious disposition of will does not substitute the supervisory powers reserved to the ordinary. Therefore, all delegated executors of a pious disposition-regardless of the office they hold - should, after discharging their duty, report to the ordinary.

In conclusion, it should be stressed that a pious disposition made by a mortis causa act, which was legally adopted, should be carried out with the utmost care. This applies not only to the administration of goods, but also to the manner in which they are used. 1300).

\footnotetext{
${ }^{51}$ DE PAOLIS, I beni temporali della Chiesa, 300. It is worth noting that in the discussion of the content of canon 1299, §2, the Commission's Coetus studiorum "De Bonis Ecclesiae Temporalibus" added that the right of heirs to be reminded of their obligations exists ex iustitia, but in the subsequent redaction of the text this was abandoned because the provision would be too rigid (nimis rigida).

${ }^{52}$ Pontifical Commission for the Revision of the Code of Canon Law, Coetus studiorum «De Bonis Ecclesiae Temporalibus», Communicationes 12, no. 2 (1980): 429.

${ }^{53}$ KenNedy, "The Temporal Goods of the Church," 1513.

${ }^{54}$ L. Chiappetta, Il Codice di Dirito Canonico, 604.

${ }^{55}$ Communicationes 12, no. 2 (1980): 429.
} 


\subsection{Trust for pious causes}

The institution of trust ${ }^{56}$ (Lat. fiducia) in canon law implies a legal act whereby the owner of estate has entrusted to a fiduciary (natural or legal person) his or her property, either through an act inter vivos or by a last will, to transfer the property for a pious cause. Trust differs from proxy in that the trustee acts in his own name and not on behalf of another person. ${ }^{57}$ Like all pious dispositions, trust is subject to the supervisory powers of an ordinary. Pursuant to canon 1302, §1, anyone who has received goods in trust for pious causes [...] should notify the ordinary of his trust and give him a list of all such goods [...] and report to the ordinary on the completion of the entrusted task (c. 1302, $\S \S 1-2 ;$ c. 1287).

Trust in the strictest sense of the term occurs when certain assets have been bestowed in trust to some religious causes. We cannot therefore speak of trust when the pastor received from the faithful a certain amount of money for the renovation of the parish church. ${ }^{58}$ The trustee must not be confused with the executor pious dispositions of will; in such a case trust would not differ from a pious non-autonomous foundation. ${ }^{59}$

Canon 1302 regulates the legal requirements for pious causes. A trustee, whether a natural or legal person, is required to notify the ordinary of the trust that has been accepted and to provide him with a list of all the assets given in trust and to inform about the obligations attached to them (c. 1302, $\S 1)$. However, the obligation to inform the ordinary only arises once the trust has been accepted (acceptit) by the trustee. Neither the value of the assets ${ }^{60}$ accepted nor the confidentiality of the trust ${ }^{61}$ is of significance. If the donor has "expressly and unconditionally" forbidden the trustee to inform the ordinary of the trust placed in him, then the trustee should not accept such a pious disposition (c. 1302, §1, latter part). Otherwise, this clause would prevent an ordinary from exercising supervision over the accepted trust (c. 1301, §2). This norm has a special application to the acceptance of trust by an inter vivos act, in which the acceptance of such trust may be refused or such a stipulation can be eliminated before accepting trust. If such a stipulation were to be attached to a will, canon 1301, $\$ 3$ should be used, according

\footnotetext{
${ }^{56}$ The institution of trust in Polish civil law has not been fully normalized.

${ }^{57}$ WósciK, Dobra doczesne Kościoła, 98.

${ }^{58}$ See also Pawluk, Prawo kanoniczne, 57.

${ }^{59}$ See also KenNEDy, "The Temporal Goods of the Church," 1515.

${ }^{60}$ Morrisey, "The Temporal Goods of the Church," 740.

${ }^{61}$ Chiappetta, Il Codice di Dirito Canonico, 604.
} 
to which clauses contrary to the ordinary's authorisation should be considered as not added. At this point, we need to distinguish between clauses added by an inter vivos act and clauses added by an act made mortis causa. Canon 1302, §1 explicitly uses the term "donor" (donator), not "testator." On the other hand, canon 1301, $\$ 3$ applies to clauses added to dispositions of the last, which can be expressed in a will and testament or a testamentary legacy.

It must be noted that canon 1302 does not specify the manner in which ordinary must be informed about the accepted trust, in particular whether it is to be written or oral. There is also no mention of the time in which the ordinary is to be informed after the trust has been accepted. Nothing prevents such a notification from being made orally, but since we are dealing with an administrative act it should be made in writing (c. 37). This is also confirmed by the case law of the Roman Rota. ${ }^{62}$ As for the period time during which the ordinary should be informed, canon 1300 should be taken into account, which provides that a pious disposition of will must be carried out with utmost diligence (diligentissime). Such a formulation leads to the conclusion that the ordinary should be informed immediately, that is, as soon as possible.

Another requirement associated with trust is the safe (in tuto) location of the property and supervision over the implementation of the pious will in accordance with canon 1301. It should be noted that the ordinary is not empowered to decide where the goods are to be located, but to oversee that they located in a safe place. If the ordinary is the diocesan bishop, he may delegate this task to the diocesan finance officer under canon 137, §1.

Once a trustee has discharged his duties, he must report to the ordinary on all property (movable or immovable) in trust and the related obligations (c. 1302, §2 in connection with c. 1301, §2).

In canon 1302, $\$ 3$, the legislator regulates in detail the question of authority to supervise trust if some goods are entrusted to a member of a religious institute or an association of apostolic life. If property given in trust is intended for the diocese or its inhabitants, or for the support of pious works, the right of supervision belongs to the diocesan bishop and to those with general ordinary executive authority (cf. c. 134, §1). In contrast, if such assets held in trust are intended for a religious institute, the ordinary mentioned in $\S \S 1$ and 2 is the local ordinary; otherwise, the major superior of a clerical institute of pontifical right or clerical society of apostolic life

\footnotetext{
${ }^{62}$ Trust effected in writing is the only instrument to determine the will of the disposer of goods, coram Parrillo, March 6, 1930, Rotae Romanae Decisiones 22 (1930): 312.
} 
association of pontifical right or this member's proper bishop in other religious institutes (c. 1302, §3).

\section{CONCLUSIONS}

The analysis of the pious dispositions of will provided for by CIC/83 should lead to the following conclusions.

1. Pious dispositions are but one example of lawful acquisition of ecclesiastical goods (c. 1259). Anyone (natural or legal person) can make a disposition of property for pious causes, unless natural or canonical law forbids it $(1299, \S 1)$.

2. The provisions of state law must be observed not only in the acceptance of legacies upon death (mortis causa), as provided for in canon 1299, $\S 2$, but also in the performance of acts among the living (inter vivos). Canon 1290 provides for compliance with the provisions of state law with respect to contracts and obligations in particular and in general. This postulate is also confirmed by canon $1284, \S 2,3^{\circ}$, which imposes an obligation on all administrators to comply with the provisions of both canonical and state law, or those issued by the founder, donor or a competent authority.

3. The supervisory authority of an ordinary governs both inter vivos and mortis causa dispositions. As far as the dispositions among the living are concerned, we need to take into account canon 1267, $\$ 2$, in which the legislator prescribes that donations of greater significance may be refused with the consent of the ordinary. If a donation is subject to a condition or a method of using it is specified, it may be accepted only after obtaining the consent of the ordinary without prejudice to canon 1295. The ordinary's consent is also required if the donation specifies its use or it includes a condition which must be fulfilled (c. 1267, §2). In the case of mortis causa dispositions, the provisions of state law must be observed (c. 1299, §2). On the other hand, should a last will include a clause excluding the powers of the ordinary with respect to the executor of the last will and testament, then the clause will be considered as non-existenT (c. 1301, §3). 


\section{BIBLIOGRAPHY}

SOURCES OF LAW

Codex Canonum Ecclesiarum Orientalium auctoritate Ioannis Pauli PP. II promulgatus, October 18, 1990. AAS 82 (1990), 1033-363. Polish translation in Kodeks Kanonów Kościołów Wschodnich promulgowany przez Papieża Jana Pawła II. Translated by Leszek Adamowicz and Marzena Dyjakowska. Lublin: Wydawnictwo Archidiecezji Lubelskiej “Gaudium,” 2002.

Codex Iuris Canonici auctoritate Ioannis Pauli PP. II promulgatus, January 25, 1983. AAS 75 (1983), pars II, 1-317. Polish translation in Kodeks Prawa Kanonicznego, approved by the Polish Episcopal Conference. Poznań: Pallottinum, 1984.

Codex Iuris Canonici auctoritate Pii X Pontificis Maximi iussu digestus. Benedicti Papae XV auctoritate promulgatus, May 27, 1917. AAS 9 (1917), pars II, 2-523.

Polish Episcopal Conference. Decree No. 1601/83/P. Polish translation in Kodeks Prawa Kanonicznego, approved by the Polish Episcopal Conference. Poznań: Pallottinum, 1984.

POLISH EPISCOPAL CONFERENCE. Instrukcja w sprawie zarządzania dobrami kościelnymi [Instruction on the administration of Church goods]. Akta Konferencji Episkopatu Polski 27 (2015): $116-40$.

Konkordat między Stolicą Apostolską i Rzecząpospolitą Polską podpisany dnia 28 lipca 1993 r. w Warszawie [Concordat between the Holy See and the Republic of Poland signed on 28 July 1993 in Warsaw]. Journal of Laws of 1998, No. 51, item. 318. Sollemnis conventio inter Apostolicam Sedem et Poloniae Rem Publicam, July 28, 1993. AAS 90 (1998), 310-29.

Pontifical Commission for the Revision of the Code of Canon Law. Acta commissionis. Communicationes 5, no. 1 (1973): 40-103.

Pontifical Commission for the Revision of the Code of Canon Law. Coetus studiorum «De Bonis Ecclesiae Temporalibus». Communicationes 12, no. 2 (1980): 388-435.

Ustawa z dnia 17 maja 1989 o stosunku Państwa do Kościoła Katolickiego w Rzeczypospolitej Polskiej [Act on the relationship between the State and the Catholic Church in the Republic of Poland]. Journal of Laws of 2018, item 380.

Ustawa z dnia 23 kwietnia 1964 r. Kodeks cywilny [Act of 23 April 1964-The Civil Code]. Journal of Laws of 2017, item 459.

\section{LITERATURE}

BączKowicz, Franciszek, Józef BAron, and Władysław Stawinoga. Prawo kanoniczne. Podręcznik dla duchowieństwa. Vol. 2. Opole: Wydawnictwo Diecezjalne św. Krzyża, 1958.

Bouscaren, Timothy L., Adam Ch. Ellis, and Francis N. Korth. Canon Law. A Text and Commentary. Milwaukee: Bruce Publishing Co, 1963.

Chiappetta, Luigi. Il Codice di Diritto Canonico. Vol. 2. Bologna: EDB, 2011.

Codex Iuris Canonici. Kodeks Prawa Kanonicznego. Komentarz. Powszechne i partykularne ustawodawstwo Kościoła katolickiego. Podstawowe akty polskiego prawa wyznaniowego. Edited by Piotr Majer. Polish edition based on Spanish edition. Kraków: Wolters Kluwer Polska, 2011.

De Paolis, Velasio. De bonis Ecclesiae temporalibus. Adnotationes in Codicem. Liber V. Rome: Gregorian University, 1986. 
De PAOLIS, Velasio. I beni temporali della Chiesa. New edition, revised and consolidated by Alberto Perlasca. Bologna: EDB, 2016.

De Paolis, Velasio. Il Codice del Vaticano II. I Beni temporali della Chiesa. Bologna: Edizioni Dehoniane, 2001.

DomaszK, Arkadiusz. Dobra doczesne Kościoła. Warsaw: Wydawnictwo UKSW, 2016.

FALCHI, Francesco. "Le pie volontà.” In AA. VV. I Beni temporali della Chiesa, 163-223. Vatican City: Libreria Editrice Vaticana, 1999.

Gałkowski, Tomasz. "Pobożny zapis i pobożna fundacja." Prawo Kanoniczne 52, nos. 3-4 (2009): 317-35.

Grabowski, Ignacy. Prawo kanoniczne wedtug nowego Kodeksu. Lviv Towarzystwo Biblioteka Religijna, 1927.

JEZIORo, Julian. "Darowizna." In Kodeks cywilny. Komentarz, $8^{\text {th }}$ ed., edited by Edward Gniewek and Piotr Machnikowski, 1634. Warszawa: Wydawnictwo C.H. Beck, 2017.

KaletA, Paweł. Kościelne prawo majątkowe. Lublin: Towarzystwo Naukowe KUL, 2014.

KaletA, Paweł. Prawne aspekty zarzadzania dobrami doczesnymi Kościoła. Lublin: Wydawnictwo KUL, 2017.

Kennedy, Robert. "The Temporal Goods of the Church." In New Commentary on the Code of Canon Law, edited by John P. Beal, James A. Coriden, Thomas J. Green, 1449-1525. Mahwah-New York: Paulist Press, 2000.

KuŹMiCKA-SUliKowSKA, Joanna. "Pojęcie testamentu." In Kodeks cywilny. Komentarz, $8^{\text {th }}$ ed., edited by Edward Gniewek and Piotr Machnikowski, 1803. Warszawa: Wydawnictwo C.H. Beck, 2017.

LóPeZ Alarcón, Marian. "Dobra doczesne Kościoła." In Codex Iuris Canonici. Kodeks Prawa Kanonicznego. Komentarz. Powszechne i partykularne ustawodawstwo Kościoła katolickiego. Podstawowe akty polskiego prawa wyznaniowego, edited by Piotr Majer, 929-82. Polish edition based on Spanish edition. Kraków: Wolters Kluwer Polska, 2011.

Morrisey, Francis G. "The Temporal Goods of the Church." In The Canon Law. Letter \& Spirit. A Practical Guide to the Code of Canon Law, edited by Gerard Sheehy, Francis G. Morrisey, Canon Law Society of Great Britain and Ireland, Canadian Canon Law Society, and Catholic Church, 707-47. Liturgical Press, 1995.

Pawluk, Tadeusz. Prawo kanoniczne wedtug Kodeksu Jana Pawta II. Vol. 4, Dobra doczesne Kościoła. Sankcje w Kościele. Procesy. Olsztyn: Włocławskie Wydawnictwo Diecezjalne, 2009.

PInTo, Pio V. Commento al Codice di Diritto Canonico. Vatican City: Libreria Editrice Vaticana, 2001.

Renken, John A. "Pious Wills and Pious Foundations." Philipine Canonical Forum 10 (2008): 69-110.

SONDEL, Janusz. Stownik łacińsko-polski dla prawników i historyków. Kraków: Universitas, 1997.

VÁzquez García-Peñuela, José María. "Pious Dispositions in General and Pious Foundations." In Exegetical Commentary on the Code of Canon Law, edited by Ángel Marzoa, Jorge Miras, Rafael Rodriguez-Ocaña, 4/1:150-93. Montreal-Chicago: Wilson \& Lafleur, 2004.

Vromant, George. De bonis Ecclesiae temporalibus. 3rd ed. Brussels: Éditions de Scheut, 1953.

WALENCIK, Dariusz. „Fundacje zakładane przez osoby prawne Kościoła Katolickiego w Polsce a fundacje pobożne.” Studia z Prawa Wyznaniowego 16 (2013): 65-91. 
WARMUZ, Agata. "Pobożne zapisy jako sposób pozyskiwania dóbr doczesnych w Kodeksie Prawa Kanonicznego z 1983 r. i partykularnym prawie polskim.” Kościót i Prawo 1 (2012): 153-66.

WóıCiK, Walenty. "Dobra doczesne Kościoła.” In Księga V. Dobra doczesne kościoła. Księga VI. Sankcje w Kościele. Vol. 4 of Komentarz do Kodeksu z 1983 r., by Walenty WóıcıK, Józef KRUKOWSKI, and Florian LEMPA, 11-112. Redakcja Wydawnictw KUL, 1987.

\section{LEGAL REQUIREMENTS FOR PIOUS DISPOSITIONS OF WILL ACCORDING TO THE 1983 CODE OF CANON LAW}

\section{Summary}

The article examines legal regulations concerning pious dispositions of will contained in the 1983 Code of Canon Law. The research problem, that is, identification of the legal requirements for a lawful acceptance of pious will, indicates that anyone can effect voluntary dispositions of property for pious causes (c. $1299, \S 1$ ), if he has the capacity to perform acts in law, subject to canon $668, \S 5$. The legislator distinguishes three ways of disposing of property for pious causes: inter vivos (e.g. by a donation agreement), 2. mortis causa (e.g. by a will and testament, a testamentary legacy, or legatum), and 3. through trust for pious causes (c. 1302). In adopting pious dispositions of will, not only canon law, but also civil law should be respected, without prejudice to the supervisory authority of the ordinary bishop expressed in canon 1301, $\S 1$ and 3; canon $1302, \S \S 1$ and 2 , and canon 1304.

Key words: pious dispositions of will; acts inter vivos; acts mortis causa; trust for pious causes.

Translated by Tomasz Pałkowski

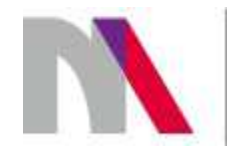

The preparation of the English version of Roczniki Nauk Prawnych (Annals of Iuridical Sciences) and its publication in electronic databases was financed under contract no. 836/PDUN/2018 from the resources of the Minister of Science and Higher Education for the popularization of science. 